\title{
Digital Engagement of Indonesian Millennials in the Prism of the Scripture, Social Media, and Religious Practices
}

\author{
T Purwanto ${ }^{1}$ \\ IAIN Syaikh Abdurrahman Siddik Bangka Belitung, Indonesia ${ }^{1}$ \\ \{ tinggalpurwanto81@gmail.com ${ }^{1}$ \}
}

\begin{abstract}
Abstact. The Qur'an is believed to be the greatest miracle of all time since its inception in the 14th Century ago. Reading and understanding of the Qur'an has given various religious practices that are sacred and practiced in various layers of Muslim society, local to international. Among millennial Muslims, religious practices based on the Qur'an develop dynamically through social media. With social media, millennial Muslim generations from various regions utilize it to build and maintain religious practices based on the Qur'an. This phenomenon shows that the Qur'an has been brought to life through social media, for example by learning, memorizing, and understanding of the Qur'an practiced through Facebook groups, Whatsapp groups, etc. Based on this phenomenon, this study reveals the millennial Muslim religious attitudes towards the Qur'an, what applications are used by millennial Muslim generations to bring the Qur'an to life in daily life, and what are the Qur'an-based religious practices formed through social media.
\end{abstract}

Keywords: Digital Engagement, Indonesian Millennials, Scripture, Social Media, and Religious Practices

\section{Introduction}

The Qur'an is believed to be the greatest miracle of all time since the beginning of its presence in the 14th Century ago [1]. Understanding of the Qur'an has given birth to various religious practices that are sacred and practiced in various of Muslim society from various generations. Abdullah Saeed[2] revealed that the Qur'an is believed to have an extraordinary influence on people's lives. This can be seen from many norms, rules, or religious practices based on his understanding of the Qur'an. All religious practices that exist among Muslims are a form of admiration and respect for the Qur'an as the word of God, whose purity is preserved [3].

Among millennial Muslim generations, religious practices in grounding the Qur'an develop dynamically through social media. Intense interaction with the Qur'an gave birth to culture [4]. The culture can be expressed through oral, written, or deeds, one of which is conveyed through social media. With social media, millennial Muslim generations from various loci, even from different parts of the world can interact and form communities to maintain religious practices and traditions built from the Qur'an, for example through friendship groups on WhatsApp, Facebook, Instagram, Line, Snapchat, and Twitter. By social media, millennial Muslim generation builds their social interactions within the frame of the practice of living the Qur'an, for example learning, understanding, memorizing the Qur'an which is carried out across space and time in cyberspace.

Interacting with the Qur'an is one of the most valuable religious experiences for a Muslim. According to Chirzin, the experience of interacting with can be revealed or expressed by expressing it through oral, written, or deed, both in the form of thoughts, emotional and spiritual experiences that are varied to find 'something different and valuable' according to background, goals, methods or theories developed [5].

This study focuses the discussion on living Qur'an in three frameworks: Al-Qur'an, Indonesian Muslim Millennial, and social media. This article seeks to explain the millennial Muslim Qur'an living model in reviving the Qur'an in daily life, what social media are widely used to bring the Qur'an alive, and how they practice living the Qur'an in their community on social media. 


\section{Method}

This study, in general, focuses on community responses or social attitudes towards the text of the Qur'an (living Qur'an)[6]. The study of the living Qur'an of certain practices which take the form of the withdrawal of the Qur'an into practical interests in the life of the people outside its textual aspects. In practice, the embryo of living Qur'an has existed since the early Islamic period. The discovery of several traditions states that the Prophet (PBUH) used a certain letter for treatment as proof that the Qur'an is functioning outside the aspects of the study of interpretation and the sciences of the Qur'an. Some figures who introduced the study of the living Qur'an include: FaridEssac, Neal Robinson, and Nasr Hamid Abu Zaid[7].

Etymologically, living Qur'an is a term composed of a combination of two words living and the Qur'an. The word "living" is derived from English, the form of the verb is formed (gerund) from "live" means life. While the word "Al-Qur'an" is the name of the Muslim holy book. For most Muslims, the term the living Qur'an is actually the words they have practiced in practice, only when the use of the term living Qur'an is put forward as if foreign and new in the study of the Qur'an. Among Muslims, these words can be interpreted in various ways. HeddyShri Ahimsa-Putra[4] interprets the word living Qur'an refers to at least three meanings. First, these words can mean "Prophet Muhammad" as a role model for the people (QS.al-Qalam: 4); Secondly, these words also refer to a society whose daily life uses the Qur'an as its reference book; and Third, these words can also mean that the Qur'an is a book that is present in a real and diverse way in the daily lives of Muslims. The third meaning is what is used in this article to highlight how the Qur'an is responded by millennial Muslim communities in the reality of daily life according to the cultural context and social interaction on social media.

With a phenomenological and ethno-graphical approach, this article will describe how the millennial living model of the Qur'an in living the Qur'an in their daily lives through social media.The main data source in this study is selected from informants of Indonesian Millennial Muslim by random sampling techniques in WhatApp Group: "Ingel-Ingel Gale" (Bangka), "IKA MAPK LAMPUNG" (Lampung), and "ALUMNI MAKSPA 2000" (Yogyakarta)

\section{Result and Discussion}

\section{Variant Living Qur'an on Social Media}

Al-Qur'an is responded dynamically and varied by the early Islamic generation to the millennial generation, not least in Indonesia[7]. Muslims' responses to the Qur'an are certainly inseparable from the influence it causes. According to Muhammad Arkoun, as quoted by Taufik Adnan Amal, the Qur'an has a very broad and deep influence on the human soul. Al-Qur'an is used by Muslims to validate behavior, justify acts of war, base various aspirations, maintain various hopes, and strengthen collective identity[8]

In general, there are three variations of the living Qur'an: written, oral, and practical. To further clarify the extent of the phenomenon of the living Qur'an will be described as follows:

\section{Living Qur'an in writing}

Writing has a significant role in the development of living Qur'an. This kind of tradition has actually been started since the first generation of Islam, the Prophet and friends. In addition to relying on memorization, they try to record the verses of the Qur'an delivered by the Prophet with writings etched on the fronds of dates, skin, bones, stones and the like[9]. After the Al-Qur'an was codified into Manuscripts during the time of Uthman ibn Affan and was distributed to Islamic areas, the writing of the Qur'an which at the beginning of the development was only used to record the Qur'an, now it can be socialized in various social media with a variety of aesthetic value, propaganda, politics and education.

Before the advent of social media, Al-Qur'an verses were used as wall hangings for houses, mosques, tombs and even Ka'bah cloths. Beautifully carved pieces commonly called calligraphy, are etched into beautiful calligraphy on walls, wood carvings, animal skins, metals (brass, silver and copper) to ceramic mosaics, each of which has interesting artistic characteristics. After the presence of social media the verses of the Qur'an are displayed in a more beautiful form by utilizing advances in digital technology.

At present in the millennial era, the writing of the verses of the Qur'an is developing in adaptation to the birth of the latest technology. Qur'anic verses are often shared in groups of friends in the form of stickers or pictures, status, wallpapers or profiles on smartphones and social media. Downloads and uploads are carried out by Muslim millennials as part of the practice of reviving the Qur'an in today's era. 
For more details, the writer tries to raise the phenomena of the living Qur'an in the written tradition on social media according to their function and role, as follows;

\section{Scriptures Profile, status and wallpaper}

Among Muslims, there are those who write scripture on their profile, status, and wallpaper as decorations, life motivators, and others. There are also a number of verses which are used as the watchword of the organization. The NahdlatulUlama (NU) organization, for example, made the QS. Ali 'Imran: 103 as his motto[10]. Likewise the Muhammadiyah organization made QS. Ali 'Imran: 104 as a basis for carrying out his mission[11].

Scripture that are uploaded or shared are usually incidental, such as sharing scripture of peace when there is an upheaval or uploading snippets of verses "innallahama'ana" in conditions to provide motivation due to adversity and so forth. These scriptures appear on social media not in empty spaces but in the form of the grounding of the Qur'anic verses in daily life. Millennials who are indeed in their daily lives cannot be separated from social media, so it becomes a necessity for religious practices related to the Koran through social media.

Millennial young Muslims live in a digital grip, so their religious understanding and practice are in social media circles. As part of self-expression in the effort of personal existence, young people pour out their understanding of religion and the Koran in their status uploads or the wallpaper they attach. This has become a symbol for the millennial generation that they are religious and understand religion in digital attachment.

\section{Share/ upload Scripture}

Some generations of millennial Muslims believe certain scripture that are believed to have many virtues[12]. For example Surah of al-Fatihah, al-Ikhlas, al-Falaq, al-Nas and AyahKursi. Then they share to the group of friends they join.

There is a millennial Muslim generation that reminds friends in a group with certain verses to carry out the commands of worship, for example the scripture of the Qur'an contain commands, such as prayer, fasting, almsgiving, infaq, alms delivered in the form of chat, stickers and others -other.

Writing is one of the media in education. In social media, living Qur'an in the form of this writing can be found in pieces of Al-Qur'an verses which are used as profiles, statuses, ring stones, and wallpapers.

Based on the phenomenon of Indonesian millennial digital involvement in the written tradition above, at least it can be understood that the actions of the millennial Muslim generation certainly have certain motives. Putting up profiles, statuses, and wallpapers in the form of fragments of the verses of the Qur'an written in beautiful Arabic calligraphy was not only for beauty or religious nuances but also contained moral and spiritual messages[13]. From this it appears that millennial Muslim generations are trying to bring the Qur'an to life on their social media.

\section{Visualization of Oral Traditions}

Oral traditions in the living Qur'an have emerged along with practices practiced by Muslims [14]. Verbal traditions appear when the Qur'an is routinely read and taught in places of worship (mosques and small mosques), even in homes, so that it becomes a routine event, especially in Islamic boarding schools to become required reading, especially after the Maghrib Prayer. In fact, specifically on Friday nights, they read Surah Yasin and sometimes coupled with Surahal-Waqi'ah.

In addition, for some people, the oral tradition also appears when the Qur'an is always memorized or memorized, both in whole or in part (1 juz to $30 \mathrm{juz}$ ), although there are also those who only memorize certain verses and letters in juz'Amma for the purpose of reading prayers and certain events, for example verses of the Koran that are recited qari'(professional readers) in special events relating to certain events, especially in the event of celebration (wedding celebration) circumcision and aqiqah.

Not only in marriage rituals, the Qur'anic observing tradition is also found in Islamic boarding school rituals, for example the tradition of the Qur'anickhataman, muqaddaman, sema'an.Even, in some certain Islamic boarding schools, they try to finish reading or memorizing the Qur'an in the graves of the kyai ancestors in order to find the blessings of the kyai.

In addition to the rituals mentioned above, the living Qur'an tradition also appears in the commemoration of the Islamic holidays (new year 1 Muharram, the birth of prophet Muhammad SAW, Isra'Mi'raj) or even formal forms such as competitions to motivate reading, memorization, understanding, 
and interpretation of the Qur'an such as in the MusabaqahTilawatil Qur'an (MTQ) competition that is incidental on a local, national and even international scale.

Nowadays the oral tradition of reading the Qur'an in the digital era can be found in Muqoddaman activities in friendship groups such as whattsApp. This kind of Muqoddaman aims to recite the Koran can be done together at the same time even though it is not in one majlis. This muqoddaman can summarize space and time.

The ODOA application (one day one Ayat) to memorize the Qur'an on YouTube is also an oral tradition of the practice of the Qur'an in the digital age. The application that was initiated by Yusuf Mansur is to facilitate Muslims memorizing the Qur'an with the method of memorizing one day one verse[15]. In the era of digitization there is indeed a phenomenon of digitalization which is the shifting of the oral tradition to the written tradition. In practice, ODOA is an oral tradition of millennial youth in reviving the memorization of the Qur'an at the time.

Based on the phenomenon of living Qur'an in the oral tradition above, at least it can be understood that efforts to present the Qur'an in the life of Muslims at any time have been carried out by Muslims from time to time.

\section{Living Qur'an in Religious Practice}

Practices in living the Qur'an tend to be mostly practiced by Muslims. This is based on the glorification of the Holy Qur'an which is considered to have a lot of influence in the lives of Muslims. Likewise what happens among millennial Muslim generations, they try to respond to the Qur'an by presenting it in certain moments and certain motives through social media. For example, the Qur'an was recited in various ceremonial official events. In the millennial era, the practice of living Qur'an has been widely recorded, then uploaded to social media groups and waiting for comments from others.

Next, the writer classifies the living Qur'an recorded in the context and dimensions of living Qur'an practice in Indonesian social media.

\section{Sending scripture to the Others}

The practice of Living Qur'an in one of them appears in the acculturation between Islam and local culture. Although this culture is considered by some Muslims to be a heresy on the one hand and precisely considered a harmonious blend for some other communities, for example, the tradition of reciting the Qur'an in the events of one's death, even after death manifested in the tradition "Yasinan" and "Tahlil" for 7 days and the commemoration of 40 days, 100 days, 1000 days and so on.

In these religious traditions, the scripture of the Qur'an are usually read that are believed to have many fadilah (virtues), for example; al-Fatihah the most important scripture; scripture the head of all the scriptures; The Yasin of the heart of the Qur'an, al-Ikhlas is equal to one third of the Qur'an[16]. From these examples, the Qur'an is believed to have a lot of fadilah for their daily lives and even for people who have died. Despite differences of opinion on the matter, certainly, the practice is still deeply rooted and still maintained in order to bring the Qur'an into the lives of Millennial Muslim generations.

Phenomenon on social media about sending scripture can be found in group chats to pray for someone. This kind of thing is now considered normal even though in reality not all group members also pray.

\section{Share scripture as Alternative medicine}

The practice of living Quran appears in the use of the Qur'an as a medicine, one of which is based on the QS. Al-Isra ': 82. The meaning of the Qur'an which differs from the scripture of the Qur'an gives birth to diverse practices in the praxis of life[17]. The practice of medicine with the scripture of the Qur'an combined with other readings can be in the form of "incantations" that have multiple functions as soul therapy, solace, treatment of physical and psychological illnesses.

The phenomenon of living Qur'an in the form of treatment using certain verses or letters in the Qur'an as practiced by some of the Prophet's friends in the past is called ruqyah[18]. For some people such practices are considered legitimate, because there were examples for example when the Prophet was still alive, there was not even a statement by the Prophet explicitly prohibiting such practices, while for others such practices were considered as a shamanic practice.

As part of religious practice using Qur'anic verses in terms of treatment on social media by millennials is uploading, liking and commenting in uploads about treatment using the Qur'an. Similarly the practice of medicine with the Qur'an is offered on social media. Like ruqyah, cupping and others. 


\section{Living Qur'an Practices in Da'wah}

For some Muslims who wrestle in the world of da'wah such as the preachers/preachers, the tradition of living Qur'an practices are found in the verses of the Qur'an that are used as argument, hujjah (argumentation), even legitimacy in order to strengthen the content of lectures, Friday sermons and recitals in the community. Some of the preachers memorized verses of the Qur'an relating to certain themes, for example at the birthday of the Prophet (QS.Ali-Imran: 144), Isra 'Mi'raj (QS. Al-Isra': 1), ahead of Ramadan (QS.al-Baqarah: 183), From some of these examples, the verses are presented according to the situation and conditions. Repetition of these verses has a psychological effect on the listener.

The practice of living the Qur'an in the da'wah dimension on social media can be found in the phenomenon of sharing and liking about matters related to the tradition of reminding each other about the implementation of worship practices such as the fasting of the sunnah, sayings of Islamic holidays and so forth.

In addition, there are also da'wahbilqishos conducted by millennial young Muslims in cyberspace, for example sharing stories of wisdom from previous scholars or inspirational stories of modern religion that are packaged in the digital era.

\section{Living Qur'an Practices in the Political}

Living Qur'an in the political dimension is done by making the verses of the Qur'an as justification and slogan in order to have political appeal, especially political parties that are based on Islam, for example QS. al-Nahl: 16, وبالنجم هم يهنتون (with the stars that they got a clue). It could even be vice versa, for example, to bring down their political opponents by throwing certain verses, for example verses QS. al-Baqarah: ولا تقربا هده الثجرة فتكون من الظالمين addressed to political parties bearing the tree. Some parties use QS verse fragments. al-Maidah: اعلون من الهو أقرب اللتقوى 8 to legitimize his party.

In the current development, the verses used are relatively the same.It is just the media used which is different. At present, the paperless trend is where the campaign is enough to be shared only in social media friendship groups, for example, scientific arguments from the Qur'an which are used as a political tradition of religious leaders to defend one of the regional leaders. Political issues surrounding the election of regional heads were warmly discussed with the arguments of the verses of the Qur'an, each of which is believed as the results of interpretation of the related verse.

In its development, discussions in cyberspace regarding the interpretation of certain verses often lead to the conflicts between different groups of Muslims, interpretations and sometimes even lead to the emergence of provocations and hoax to defend the narratives and arguments he believes.

\section{Conclusion}

From the brief discussion in this article, it can be seen that this study of the living Qur'an seeks to highlight how the Qur'an is addressed to and responded by millennial young people in the reality of daily life on social media. As for the case or phenomenon that appears among millennial young Muslims as a response to the Qur'an, it can be classified into three forms; written, oral and practical traditions. Each of these traditions has motives, goals, obsessions, backgrounds not only to present the Qur'an in their daily lives but more than that it functions outside the text as a personal and group response to the Qur'an.

\section{References}

[1] M. Q. Shihab, “ Membumikan” Al-Quran: fungsi dan peran wahyu dalam kehidupan masyarakat. Mizan Pustaka, 2007.

[2] A. Saeed, The Qur'an: an introduction. Routledge, 2008.

[3] T. Purwanto, "FENOMENA LIVING AL-QUR'AN DALAM PERSPEKTIF NEAL ROBINSON, FARID ESACK DAN ABDULLAH SAEED," MAWA'IZH J. DAKWAH DAN Pengemb. Sos. Kemanus., vol. 7, no. 1, pp. 103-124, 2016.

[4] H. S. Ahimsa-Putra, "The Living al-Qur'an: Beberapa Perspektif Antropologi," Walisongo J. Penelit. Sos. Keagamaan, vol. 20, no. 1, pp. 235-260, 2012.

[5] M. Chirzin, “dkk. Metodologi Penelitian Living Qur'an dan Hadis.” Yogyakarta: TH-Press, 2007.

[6] S. Syamsuddin, "Penelitian Literatur Tafsir/Ilmu Tafsir: Sejarah, Metode dan Analisis 
Penelitian," in dalam Makalah Seminar, Yogyakarta, 1999.

[7] M. Mansur, "Living Qur'an dalam Lintasan Sejarah Studi Qur'an," Metodol. Penelit. Living Qur'an dan Hadis, Ed. by Sahiron Syamsuddin. Yogyakarta Teras, 2007.

[8] T. A. Amal, "sejarah rekonstruksi al-Qur'an," Yogyakarta FKBA, 2001.

[9] A. Rippin, The Blackwell companion to the Qur'an. John Wiley \& Sons, 2008.

[10] M. Irham, "Etos Kerja Dalam Perspektif Islam," SUBSTANTIA, vol. 14, no. 1, pp. 9-24, 2012.

[11] S. ALFIYAH, "Strategi Dakwah Muhammadiyah Daerah Banyumas.” IAIN, 2014.

[12] A. Mujahidin, "Analisis Simbolik Penggunaaaan Ayat-ayat Al-Quran Sebagai Jimat Dalam Kehidupapan Masyarakat Ponorogo," KALAM, vol. 10, no. 1, pp. 43-64, 2016.

[13] I. Gusmian, "LIVING QUR'AN." IAIN SURAKARTA, 2013.

[14] M. K. Anwar, "living Hadis," Farabi J. Ushuluddin Islam. Thought, vol. 12, no. 1, pp. 72-86, 2015.

[15] K. Anwar and M. Hafiyana, "Implementasi Metode ODOA (One Day One Ayat) dalam Meningkatkan Kemampuan Menghafal Al-Quran,” J. Pendidik. Islam Indones., vol. 2, no. 2, pp. 181-198, 2018.

[16] J. Rakhmat and T. Surjaman, Psikologi komunikasi. Remaja Rosdakarya, 1999.

[17] A. Atabik, "The Living Qur'an: Potret Budaya Tahfiz al-Qur'an di Nusantara," J. Penelit., vol. 8, no. 1, pp. 161-178, 2014.

[18] H B Jass, PEMBACAAN AYAT AYAT AL-QUR'AN DALAM. . 